\title{
4.1B suppresses cancer cell proliferation by binding to EGFR P13 region of intracellular juxtamembrane segment
}

\author{
Fumin Xue ${ }^{1,2}$, Chao An ${ }^{3}$, Lixiang Chen ${ }^{4}$, Gang Liư ${ }^{5}$, Feifei Ren², Xinhua Guo ${ }^{6}$, Haibin Sun, Lu Mei ${ }^{1}$, \\ Xiangdong Sun ${ }^{2}$, Jinpeng $\mathrm{Li}^{1}$, Youcai Tang ${ }^{8}$, Xiuli $\mathrm{An}^{9^{*}}$ and Pengyuan Zheng ${ }^{1^{*}}$
}

\begin{abstract}
Background: Gastric cancer (GC) has high incidence and mortality worldwide. However, the underlying mechanisms that regulate gastric carcinogenesis are largely undefined. 4.1B is an adaptor protein found at the interface of membrane and the cytoskeleton. Previous studies demonstrated that 4.1B serves as tumor suppressor.

Results: We showed that 4.1B expression was decreased or lost in most GC patients. The expression pattern of it was tightly correlated with tumor size, TNM stage and overall survival (OS). We further showed that 4.1B inhibited the proliferation of two GC cell lines, MGC-803 and MKN-45, by impeding the EGFR/MAPK/ERK1/2 and PI3K/AKT pathways. A similar phenotype was also observed in immortalized mouse embryonic fibroblasts (MEF) derived from wild type (WT) and 4.1B knock-out (BKO) mice. Additionally, immunofluorescence (IF) staining and Co-IP showed that protein $4.1 \mathrm{~B}$ bound to EGFR. Furthermore, the FERM domain of 4.1B interacted with EGFR through the initial 13 amino acids (P13) of the intracellular juxtamembrane (JM) segment of EGFR. The binding of 4.1B to EGFR inhibited dimerization and autophosphorylation of EGFR.

Conclusion: Our present work revealed that 4.1B plays important regulatory roles in the proliferation of GC cells by binding to EGFR and inhibiting EGFR function through an EGFR/MAPK/ERK1/2 pathway. Our results provide novel insight into the mechanism of the development and progression of GC.
\end{abstract}

Keywords: Gastric cancer, Protein 4.1B, EGFR, Sp1, Tumor suppressor

\section{Background}

Annually, more than 720,000 people die from gastric cancer (GC) worldwide, making it the second leading cause of cancer-related deaths around the world [1]. Half of all GC cases occur in East Asia (mainly in China), of which a total 677,000 cases occur in developing countries [2]. The incidence of GC is $13.9 \%$ in total digestive tract and the trend increases with years [3]. Current therapeutic strategies for GC include mucosectomy by endoscopy, gastrectomy, and/ or chemotherapy. However, the 5-year overall survival is still only $40 \%$ [4]. Therefore, more effective treatment options are urgently needed. Understanding the underlying

\footnotetext{
*Correspondence: xan@nybc.org; Medp7123@126.com

${ }^{9}$ Laboratory of Membrane Biology, New York Blood Center, New York, NY 10065, USA

'Department of Gastroenterology, the Fifth Affiliated Hospital of Zhengzhou University, Zhengzhou 450052, Henan, China

Full list of author information is available at the end of the article
}

mechanisms that drive GC pathogenesis will facilitate the development of better therapeutic strategies for GC patients.

Erythrocyte Membrane Protein Band 4.1 Like 3 (EPB41L3 or 4.1B) belongs to the protein 4.1 superfamily, of which there are more than 40 members. This superfamily is classified into five subgroups: Protein 4.1 subfamily, ERM proteins, Talin-related molecules, PTPH (protein tyrosine phosphatases) proteins, and NBL4 (novel band 4.1-like 4) proteins based on protein sequence homology [5]. Protein 4.1B together with 4.1R, $4.1 \mathrm{G}$, and $4.1 \mathrm{~N}$ belong to the protein 4.1 subfamily and they are encoded by four paralogous genes [6]. The four members of protein 4.1 subfamily contain four highly conserved functional domains: the membrane-binding FERM domain [7-9], a FERM-adjacent (FA) regulatory domain [10], a spectrin-actin binding domain (SABD) [11, 12], 
and a C-terminal domain (CTD) unique to the 4.1 proteins [13]. It has been reported that $4.1 \mathrm{~B}$ is decreased in several cancers, such as renal cell carcinoma [14], ovarian cancer [15], liver cancer [16], and colon cancer [17]. A few studies have addressed the relationship between protein 4.1B and GC [18, 19]; however, details of the functional role of 4.1B in GC development and progression have not been unearthed.

Epidermal growth factor receptor (EGFR) belongs to the Erb receptor tyrosine kinase family, of which there are four members: ErbB1 (EGFR), ErbB2 (c-Neu), ErbB3 (HER3), and ErbB4 (HER4) subtypes). EGFR contains 1186 aa and consists of an extracellular ligand-binding domain, a transmembrane domain, and an intracellular domain. Additionally, the intracellular domain is divided into 3 unique segments, namely the juxtamembrane (JM) segment, tyrosine kinase (TK) domain, and a $\mathrm{COOH}$-terminal region [20-22]. EGFR plays critical roles in regulating metabolism, growth, and differentiation [23]. Numerous studies have documented EGFR overexpression in tumors, such as squamous carcinoma [24] and some glioblastomas [25]. EGFR has potent mitogenic activity that can either stimulate or inhibit growth of a large variety of normal and malignant cells in vitro.

In this article, we report that 4.1B was downregulated in GC specimens and that 4.1B inhibited GC and MEF cell proliferation through the EGFR/MAPK/ERK1/2 and PI3K/AKT pathways. We further demonstrate that 4.1B bound to EGFR through the interaction of the FERM domain of $4.1 \mathrm{~B}$ with the P13 of EGFR JM segment. Interestingly, this binding blocked EGFR dimerization and autophosphorylation. Our study provides evidence of the molecular mechanism through which 4.1B inhibits cell proliferation.

\section{Materials and methods \\ Mice}

Wildtype C57BL/6 mice were purchased from The Jackson Laboratory. The 4.1B knockout mice have been previously reported [26, 27] were kindly provided by Dr. J. Kissil (TheWistar Institute). These mice were housed in the animal facility of New York Blood Center under specific pathogenfree (SPF) conditions accredited by the American Association for Laboratory Animal Care. Four-week-old athymic $\mathrm{BALB} / \mathrm{c}$ nude mice used for tumorigenicity assays were purchased from the animal center of Beijing, China. They were housed in the animal room of the fifth affiliated hospital of Zhengzhou University under SPF conditions. All animal experiments were approved by the Institutional Animal Care and Use Committee.

\section{GC cell lines and patient specimens}

The GC cell lines MGC-803 and MKN-45 were purchased from Cell Bank of Type Culture Collection of the Chinese
Academy of Sciences, Shanghai Institute of Cell Biology. They were cultured in RPMI 1640 medium (HyClone, USA) supplemented with $10 \%$ fetal bovine serum (FBS, Invitrogen, USA). All cells were cultured in a humidified incubator at $37^{\circ} \mathrm{C}$ and $5 \% \mathrm{CO}_{2}$.

This study included $102 \mathrm{GC}$ patients who underwent gastrectomy from Jan 2011 to Jan 2013. The normal controls were located at least $5 \mathrm{~cm}$ away from the tumor. These GC paraffin-embedded tissue sample collections were approved by the Ethics Committee of the fifth affiliated hospital of Zhengzhou University, Henan, China. The 102 patient specimens included 59 males and 43 females. The patient age range was from 25 to 76 years old. Histological grades were classified according to the WHO classification as highly (grade I), moderately (grade II), and poorly differentiated (grade III). The TNM stage was performed according to the AJCC8 classification.

\section{Immortalized MEF cells preparation and culture}

Isolation of primary mouse embryo fibroblasts (MEF) from day 13.5 embryos (E13.5) of $4.1 \mathrm{~B}^{+/+}$and $4.1 \mathrm{~B}^{-/-}$ C57BL/6 mice was performed as previously described [28]. Briefly, the head and internal organs were removed. The remaining embryonic tissues were minced using a pair of scissors and immersed in $0.25 \%$ trypsin overnight at $4{ }^{\circ} \mathrm{C}$. After $24 \mathrm{~h}, \mathrm{MEFs}$ were collected after centrifugation at $1500 \mathrm{rpm}$ and maintained in Dulbecco Modified Eagle Medium (DMEM) containing 10\% fetal bovine serum (FBS, GIBCO, USA) and $100 \mu \mathrm{g} / \mathrm{ml}$ penicillin/ streptomycin (LEAGENE, China). After two passages, the MEFs were immortalized by retroviral transduction of the SV40 large $\mathrm{T}$ antigen. MEFs were cultured in DMEM containing $10 \% \mathrm{FBS}$ and incubated at $37^{\circ} \mathrm{C}$ in a humidified environment with $5 \% \mathrm{CO}^{2}$.

\section{Cloning of 4.1B cDNA from MEF cells}

Total RNA was isolated from wild type and 4.1B knockout MEF cells by the RNeasy mini kit (Qiagen, Germany). $1 \mu \mathrm{g}$ of RNA was reverse-transcribed into cDNA using random primers and M-MuLV reverse transcriptase (New England Biolabs, USA). Reverse transcription was performed according to the manufacture instructions (New England Biolabs, USA). Primers used to amplify 4.1B transcripts were: 4.1B ATG-1 FOR: 5' ATGACGACCGAATCAGGATCAGACTCAG-3'; 4.1B RE: 5' -TCAATCCTCTCCGTCCTCTGGTGTGATT-3'. PCR was performed in a $50 \mu \mathrm{l}$ reaction mixture containing $2 \times$ Hotstar Taq Plus Master Mix DNA Polymerase (Qiagen, Germany), $10 \mu \mathrm{M}$ primer each, $200 \mathrm{ng}$ of template cDNA, and double distilled $\mathrm{H}_{2} \mathrm{O}$. Cycling conditions were $30 \mathrm{~s}$ at $94^{\circ} \mathrm{C}$ for denaturation, $30 \mathrm{~s}$ at $55^{\circ} \mathrm{C}, 4$ $\min$ at $68^{\circ} \mathrm{C}$ for extension, and a final extension for 5 $\min$ at $72^{\circ} \mathrm{C}$. Cycle numbers were 45 for ATG-1 4.1B. 


\section{Plasmid constructions}

For mammalian cell expression, ATG-1-4.1B was cloned into pEGFP-C3 vector using restriction enzymes $\mathrm{XhoI}$ and BamHI upstream and downstream, the primers used were: 4.1B forward 5'-AAACTCGAGATGACGACCGAAT CAGGATCAGACTCAG-3'; 4.1B reverse 5'-AAAGGA TCCCGTCAATCCTCTCCGTCCTCTGGTGTGATT-

3 '. The 4.1B $130-\mathrm{kDa}$ protein was cloned into pET-31b (+) with NsiI and XhoI upstream and downstream, respectively. The various domains of $4.1 \mathrm{~B}$ were cloned into pGEX4T-2 or pET28c vector. The EGFR intracellular fragments EGFR1, EGFR2 and the EGFR1 without 13 amino acid fragment $\left(E G F R 1 \triangle{ }^{\circ} a 13\right)$ were cloned into pGEX4T-2 vector; using restriction enzymes SmaI and Xhol upstream and downstream.

The primers used as follow: the first fragment of intracellular EGFR (EGFR1) forward 5' ATCCCGGGCGAA GACGTCACATTGTTCGA 3'; the first fragment of intracellular EGFR (EGFR1) deletion the initial 13 amino acid (EGFR1 $\triangle$ aa13) forward 5' -ATCCCGGGCTGCTT CAAGAGAGAGAGCTC-3'; the first fragment of EGFR (EGFR1) reverse 5'-ATCTCGAGCGTCAAACAAGGTA GCGCTGTGGGTC-3'; the second fragment of intracellular EGFR (EGFR2) forward 5'-ATCCCGGATC CAGGGGGATGAAAGAATG-3'; the second fragment of intracellular EGFR (EGFR2) reverse 5'-CGCTCG AGCGTCATGCTCCAATAAACTCACT-3'. Synthesizing of polypeptide of EGFR P13 amino acid and mutants of P13 amino acid, the EGFR polypeptide used were: EGFR P13-RRRHIVRKRTLRR, The mutants of EGFR P13 (RRR- $A A A$ ): $A A A$ HIVRKRTLRR; EGFR P13 (RKR$A A A)$ RRRHIVAAATLRR; EGFR P13 (RR-AA): RRRHIVRKRTLAA.

\section{Immunofluorescence}

For confocal immunofluorescence microscopy assay, cells were grown on Lab-Tek ${ }^{\mathrm{m}}$ Chambered Coverglass (Thermo Fisher Scientific, USA) pre-coated with $10 \mu \mathrm{g} /$ $\mathrm{ml}$ fibronectin (Gibco, USA). Cells were fixed with $1 \%$ paraformaldehyde (LEAGENE, China) for $15 \mathrm{~min}$ and then permeabilized with $0.1 \%$ Triton X-100 (Sigma-Aldrich, USA) in $0.25 \%$ paraformaldehyde-PBS for $15 \mathrm{~min}$ at room temperature, followed by blocking in 10\% horse serum (Gibco, USA), $0.1 \%$ Triton X-100 in PBS for 30 min to minimize nonspecific antibody binding. Cells were then incubated with primary antibodies at $4{ }^{\circ} \mathrm{C}$ overnight and then washed with PBS 3 times. This was followed by incubation with the appropriate secondary antibody at room temperature for $30 \mathrm{~min}$. The secondary antibodies were donkey anti-rabbit (Thermo Fisher Scientific, USA) and donkey anti-mouse IgG (Thermo Fisher Scientific, USA) labeled with Alexa Fluor 488 or Alexa Fluor 594. To-pro-3 (Invitrogen, USA) was used to stain the nucleus. Images were collected on a Zeiss
LSM510 META confocal microscope (Germany) using $\times 63$ oil-immersion objective.

\section{Cell proliferation assay}

$5 \times 10^{5}$ cells were seeded in the cell culture dish and counted on day 3 , day 5 , and day 7 . The untreated MGC-803 and MKN-45 cells were cultured in RPMI1640 with $10 \%$ FBS. The transfected MGC-803 and MKN-45 cells underwent selection with G418 (Gibco, USA) and puromycin (Millipore, USA). The experiment was independently repeated three times.

\section{Cell transfection}

MGC-803 and MKN-45 cells were seeded in six-well plates with RPMI-1640 with 10\% FBS. When cells reached $80-85 \%$ confluence, MGC-803 cells were transfected with $3 \mu \mathrm{g} / \mathrm{ml}$ pEGFP-4.1B or pEGFP-C3 plasmid using lipofectamine 2000 (Invitrogen, USA) following the manufacturer's instructions. Stably transfected cells were obtained by selection with $400 \mu \mathrm{g} / \mathrm{ml} \mathrm{G} 418$ for 24 h. To knockout 4.1B, Plasmid 4.1B double nickase plasmid (sc-406,853-NIC) and control nickase plasmid (sc437,281 ) were used to transfect MKN45 cells. Stably transfected cells were obtained after selection with $8 \mu \mathrm{g} /$ $\mathrm{ml}$ puromycin for $36 \mathrm{~h}$.

MKN-45 4.1B-/- cells and 4.1B KO MEF cells were transfected with small interfering RNAs (siRNAs) (100 $\mathrm{nM}$ ) against $\mathrm{Sp} 1$ which were purchased from GenePharma (China, shanghai). All siRNAs were transfected using lipofectamine 2000 following the manufacturer's instructions. The knockdown efficiencies were detected by Real-time PCR and western blotting after $48 \mathrm{~h}$. The sequences of siRNAs were as follows: human and mouse negative control FAM 5' - UUCUCCGAACGUGUCACGUTT - 3'; human Sp1 5' - CCAUUAACCUCAGUGCAUUTT - 3'; mouse Sp1 5' -GCGGCAAAGUAUAUGGCAATT- 3'.

\section{Western blot analysis}

Cells were lysed with RIPA buffer $(150 \mathrm{mM} \mathrm{NaCl}, 25$ $\mathrm{mM}$ Tris- $\mathrm{HCl} \mathrm{pH} 7.4,0.1 \%$ SDS, $1 \%$ Triton X-100, $1 \%$ deoxycholate, $2 \mathrm{mM}$ EDTA, Millipore, USA) supplemented with protease inhibitor (Sigma-Aldrich, USA) and phosphatase inhibitor (Roche, Basel, Switzerland) for $30 \mathrm{~min}$ on ice. The supernatant was collected by centrifugation with $14,000 \mathrm{rpm}$ and the protein concentration was measured with BCA kit (Thermo Fisher Scientific, USA). Protein samples $(50 \mu \mathrm{g})$ were separated by $10 \%$ SDS-PAGE gels and transferred to nitrocellulose membranes. The membranes were incubated with primary antibodies overnight at $4{ }^{\circ} \mathrm{C}$. Membranes were then washed with TBS-T and then incubated with secondary antibodies for $1 \mathrm{~h}$. Signals were detected with ECL kit (Thermo Fisher Scientific, USA) by Chemi Doc ${ }^{\mathrm{Tn}}$ XRS+ with Image Lab ${ }^{\text {tw }}$ Software (Bio-Rad, USA). 
The primary antibodies included $4.1 \mathrm{~B}(\mathrm{HP})$ which was characterized and used in our previously published studies [29], p-EGFR (Cell Signaling Technology, USA, \#3777), EGFR (Cell Signaling Technology, USA, \#2232), p-ERK1/2 (Abcam, UK, ab50011), ERK1/2 (Abcam, UK, ab17942), p-AKT (Cell Signaling Technology, USA, \#4060), AKT (Cell Signaling Technology, USA, \#4691), p-JNK (Abcam, UK, ab76572), JNK (Abcam, UK, ab208035), p-p38 (Abcam, UK, ab178867), p-38 (Abcam, UK, ab27980), Sp1 (Santa Cruz Biotechnology, CA, sc-17,824), $\beta$-actin (Santa Cruz Biotechnology, CA, sc-47,778).

\section{Immunohistochemistry}

The paraffin-embedded patient specimens were sectioned at $3 \mu \mathrm{m}$ thickness and mounted on glass slides. After deparaffinization and dehydration with xylene and an alcohol gradient, the slides were washed with PBS. Antigen retrieval was carried out by heating slides for $20 \mathrm{~min}$ in citrate buffer (LEAGENE, China). Endogenous peroxidase activity was blocked with $3 \%$ hydrogen peroxide and $10 \%$ goat serum (Beijing Zhongshanjinqiao Biotechnology Co. LTD, China) for $30 \mathrm{~min}$ at room temperature. The slides were incubated with an anti-4.1B primary antibody at $4{ }^{\circ} \mathrm{C}$ overnight. Biotinylated goat anti-rabbit IgG antibody was then added to the slides for $30 \mathrm{~min}$ at $37^{\circ} \mathrm{C}$ after washing with PBS. Diaminobenzidine (Beijing Zhongshanjinqiao Biotechnology Co. LTD, China) was used to stain the slides for about 1 to $5 \mathrm{~min}$. Slides were then counterstained with hematoxylin (LEAGENE, China) and dehydrated in xylene and mounted with permount.

The result was assessed by an addition of the percentage of positive tumor cells and the cytoplasmic staining intensity. The percentage of positive tumor cells was scored as 0 (<5\%), 1 (5-25\%), 2 (25-50\%), 3 (50-75\%), or 4 (> 75\%). The staining intensity was scored as 0 (negative), 1 (weak), 2 (moderate), or 3 (strong). A sample was defined as negative if the final score was $0-3$ and as positive if the final score was $4-7$. $P$ values were calculated using the chisquared test.

\section{Tumorigenicity analysis}

Five-week-old BALB/C nude mice were injected with $3 \times 10^{6}$ of each transfected cell type suspended in $200 \mu \mathrm{l}$ serum-free RPMI-1640. The cells were inoculated into the subaxillary region for the tumorigenic assay. Tumors were palpable after 1 week and monitored every 3 days. The tumor size was measured with a Vernier caliper and tumor volume was calculated as follows: volume $=1$ / $2 \times$ (long axis $) \times(\text { short axis })^{2}$. Experimental mice were euthanized after 2 weeks. The resected tumors were fixed with $10 \%$ formalin, embedded in paraffin, and sectioned $(3 \mu \mathrm{m})$. Sections were stained with hematoxylin and eosin (H\&E) (LEAGENE, China) and Ki-67 (LEAGENE, China) for light microscopy examination.
RNA isolation, reverse transcription, and PCR analysis Total RNA was isolated from wild type and 4.1B knock-out MEF cells, MGC-803 pEGFP-C3 control and pEGFP-4.1B overexpression cells by total RNeasy mini kit (Qiagen, Germany). $1 \mu \mathrm{g}$ of total RNA from each sample was reversetranscribed into cDNA following the manufacturer's protocol (TOYOBO, Japan). The primers used for PCR were as follows: human 4.1B forward, 5'- CTAGCAGTAAACTC TCTCGGTCT - 3' and reverse 5' - TGGAGCGTTTCTCT ACATCACA - 3'; human EGFR forward, 5'- TTGCCG CAAAGTGTGTAACG $-3^{\prime}$ and reverse 5'- GTCACC CCTAAATGCCACCG - 3'; human SP1 forward, 5'-AAGTAATCCCACAGTTCCAGACC $-3^{\prime}$ and reverse $5^{\prime}$ GTTGGTTTGCACCTGGTATGATC-3'; human GAPDH forward, 5' - AGAAGGCTGGGGCTCATTTG - 3' and reverse 5' - AGGGGCCATCCACAGTCTTC - 3'; mouse 4.1B forward, 5'- AAGAGCCACAGAGGAATGACG - 3' and reverse $5^{\prime}$ - TCCTTGGCATGGTGTAAGTCC - 3'; mouse EGFR forward, $5^{\prime}$ - AATGTTCCCATCGCTGTCGT $-3^{\prime}$ and reverse 5' - GGCAGACCAGACAGTCACTC - 3'; mouse SP1 forward, $5^{\prime}$ - TACCACCCTAACACCCATTGC $-3^{\prime}$ and reverse $5^{\prime}$ - TCCCTGAAGTACCCAATGCAC-3'; mouse $\beta$ - actin forward, 5'- GCTTCTTTGCAGCT CCTTCGT $-3^{\prime}$ and reverse $5^{\prime}$ - CCAGCGCAGC GATATCG -3'. PCR was performed following the manufacturer's instructions (TOYOBO, Japan). The reaction mixture included $25 \mu \mathrm{l}$ SYBR Green Real-time PCR Master Mix, $0.4 \mu \mathrm{M}$ primer each, $5 \mu \mathrm{l}$ of template $\mathrm{cDNA}$, and double distilled $\mathrm{H} 2 \mathrm{O}$ and total volume is $50 \mu \mathrm{l}$. And cycling conditions were $60 \mathrm{~s}$ at $95^{\circ} \mathrm{C}$ for denaturation, $15 \mathrm{~s}$ at $60^{\circ} \mathrm{C}$ or annealing, $45 \mathrm{~s}$ at $72{ }^{\circ} \mathrm{C}$ for extension. Cycle numbers were 40 . The results were collected with AriaMx Real-time PCR system (Agilent Technologies, USA).

\section{Co-immunoprecipitation}

MEFs were lysed with ice-cold lysis buffer (50 mM HEPES, pH 8.3, 420 mM KCl, 0.1\% NP-40, 1 mM EDTA) supplemented with a proteinase inhibitor cocktail (Roche, Basel, Switzerland) for $30 \mathrm{~min}$ on ice. Supernatants were collected after centrifugation at $15,000 \mathrm{~g}$ at $4{ }^{\circ} \mathrm{C}$ for $10 \mathrm{~min}$ and protein concentration was determined by the Bradford method using BSA as a standard (Bio-Rad, USA). Protein extracts $(500 \mu \mathrm{g}$ per sample) were incubated with either $5 \mu \mathrm{g}$ anti-4.1B-HP or anti-EGFR antibody or preimmune IgG in $500 \mu \mathrm{l}$ of Co-IP buffer (Active motif, CA) at $4{ }^{\circ} \mathrm{C}$ overnight with rotation. The immunoprecipitates were isolated using Protein-G beads (Millipore, USA) and separated by $10 \%$ SDS-PAGE and then transferred to a nitrocellulose membrane. The membrane was probed with antibodies against EGFR or 4.1B-HP.

\section{Pull-down assay}

GST-tagged recombinant different fragment cytoplasmic domain of EGFR and various functional domains of $4.1 \mathrm{~B}$ 


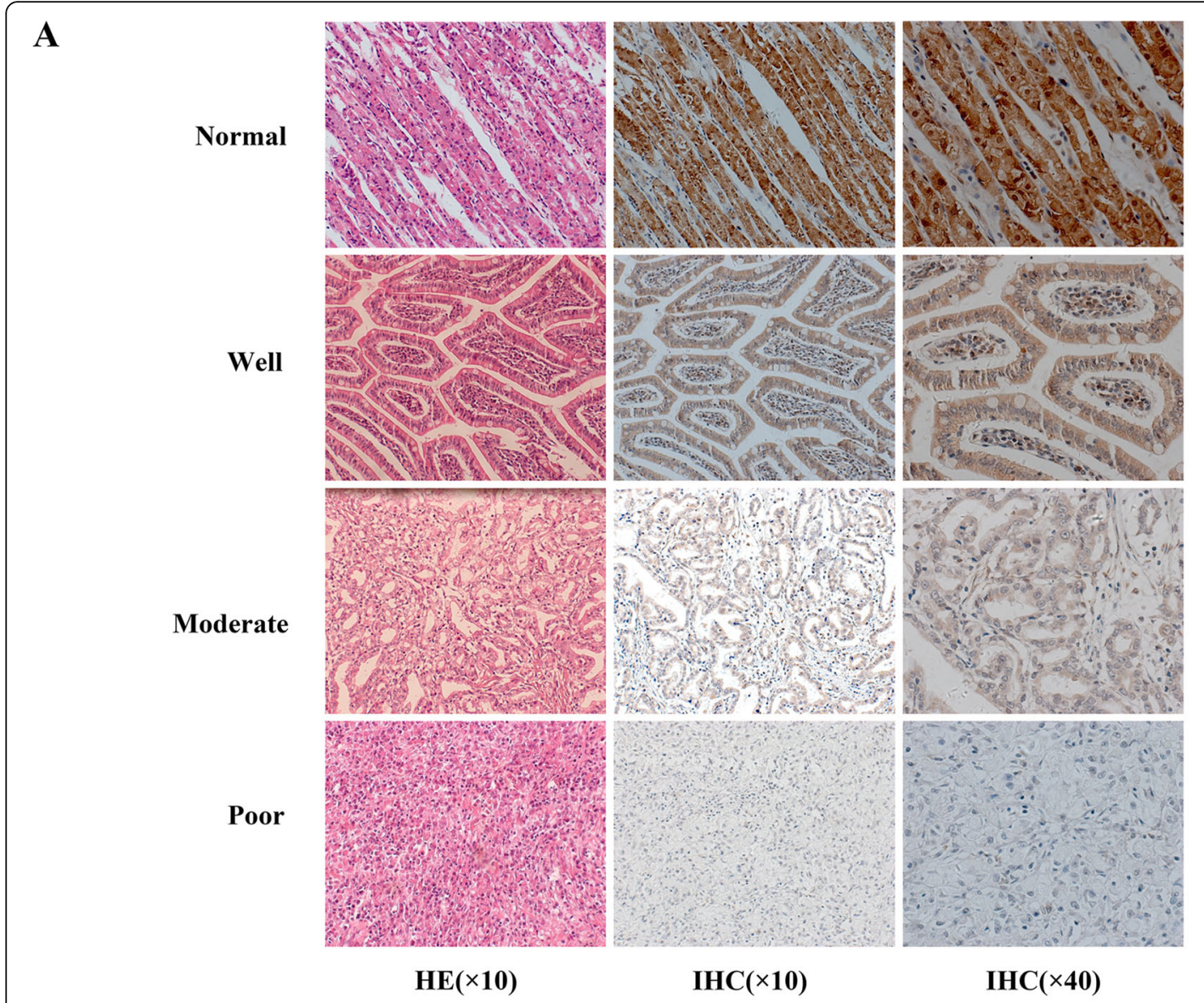

B

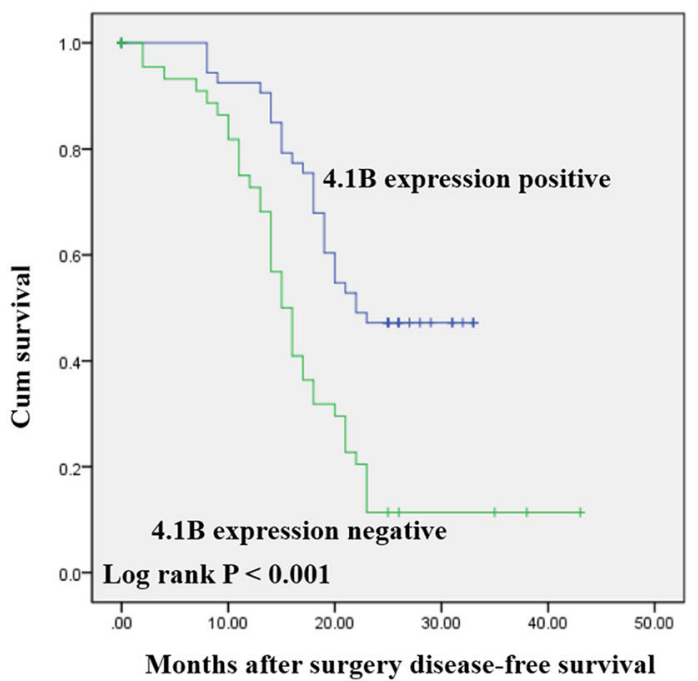

C

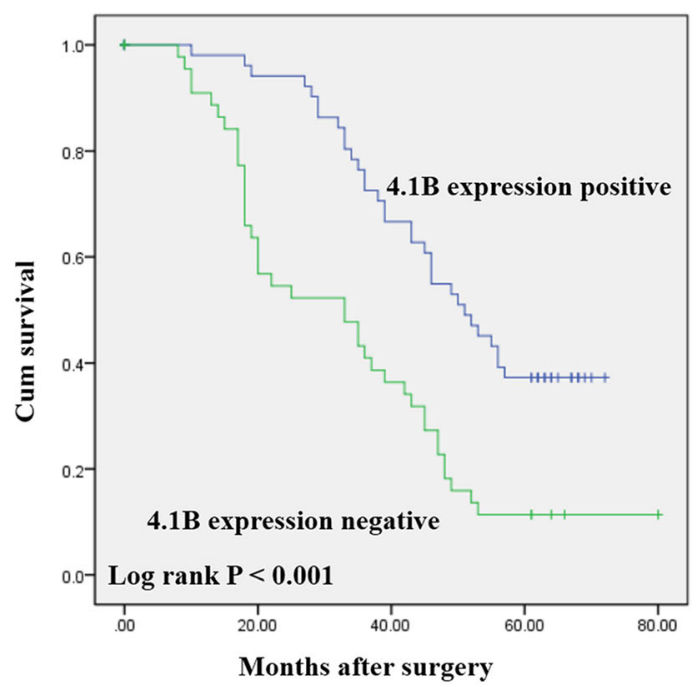

Fig. 1 4.1B expression levels in GC primary tumor and the correlation with prognosis. a Representative images of immunohistochemical staining for protein 4.1B expression. Normal gastric tissues (adjacent noncancerous gastric tissues of GC specimens (>5 cm)) and GC specimens (well, moderate and poor) were stained for 4.1B by an anti-4.1B HP antibody. The brown color represents positive staining for 4.1B expression. Cells nuclei were counterstained with hematoxylin (blue). The purple color staining is HE staining. Original magnification: $\times 10$ and $\times 40$. b Disease-free survival was analyzed by Kaplan-Meier analysis in GC patients with 4.1B protein positive (score 4-7) and negative (score 0-3) specimens. c Overall survival was analyzed by Kaplan-Meier analysis in GC patients with 4.1B protein positive (score 4-7) and negative (score 0-3) specimens 
Table 1 The difference of 4.1B expression in GC and adjacent normal tissue specimens

\begin{tabular}{|c|c|c|c|c|c|c|}
\hline \multirow[t]{2}{*}{ Variables } & & \multicolumn{2}{|c|}{$\underline{\text { gastric adenocarcinoma }}$} & \multirow[t]{2}{*}{ Total } & \multirow[t]{2}{*}{$x^{2}$} & \multirow{2}{*}{$\begin{array}{l}P \\
\text { value }\end{array}$} \\
\hline & & negative & positive & & & \\
\hline \multirow[t]{2}{*}{ Adjacent normal tissue } & negative & 8 & 1 & 9 & & \\
\hline & positive & 38 & 55 & 93 & 32.230 & $<0.001$ \\
\hline Total & & 46 & 56 & 102 & & \\
\hline
\end{tabular}

were coupled to glutathione-Sepharose- $4 \mathrm{~B}$ beads at room temperature for $30 \mathrm{~min}$. Immobilized streptavidin beads were mixed with biotinylated 13 EGFR peptide prior to incubation with GST-tagged 4.1B domains. Beads were pelleted and washed. His-tagged 4.1B with different GSTtagged cytoplasmic domain of EGFR and GST-tagged 4.1B domains with biotinylated 13 EGFR peptide were added to the coupled beads in a final volume of $100 \mu \mathrm{l}$. The final concentration of the coupled protein was $2 \mu \mathrm{M}$. The mixture was incubated for $1 \mathrm{~h}$ at room temperature, pelleted, washed and eluted with $10 \%$ SDS. The pellet was analyzed by SDS-PAGE. The binding of His-tagged 4.1B domains with EGFR intracellular fragments was detected by western blot using anti-His antibody. The binding of GSTtagged 4.1B domains with 13 EGFR peptide was detected by western blot using anti-GST antibody. GST was used as negative control in all experiments.

\section{Statistics}

All statistical analyses were performed by using SPSS 20.0 software. Difference between 2 groups was determined by Student $\mathrm{t}$ test orx ${ }^{2}$ test. DFS and OS were analyzed by Kaplan-Meier analysis with the log-rank test applied for comparison. And the survival data were examined by univariate and multivariate COX proportional hazards model. Variables with a value of $p<0.05$ in univariate were checked in multivariate analysis by COX regression analyses. And two-sided $p<0.05$ was considered statistical significance.

\section{Results}

\section{Expression of 4.1B in GC patients and GC cell lines}

To explore the relationship between $4.1 \mathrm{~B}$ and GC, we analyzed 4.1B expression in 102 gastric adenocarcinoma patient samples by immunochemistry. The results revealed that $4.1 \mathrm{~B}$ was significantly different between tumor tissues and their matched adjacent non-tumor tissues (Fig. 1a; Table 1; $\chi^{2}=32.23 ; p<0.001$ ). There was strong expression of $4.1 \mathrm{~B}$ in the cell membrane and cytoplasm of the majority of adjacent non-tumor tissues (91.17\%) (Fig. 1a). In contrast, tumor tissues showed little to no expression of 4.1B (Fig. 1a). There was a negative correlation between 4.1B expression level with tumor size, pathologic differentiation, lymph node metastasis and TNM stage (Table 2). There was no significant association between 4.1B expression and patients age, gender, Helicobacter pylori infection, tumor location, WHO classification, vascular invasion, depth of invasion and neural invasion (Table 2).

To further explore the correlation of $4.1 \mathrm{~B}$ and prognosis, we analyzed the median survival about the disease-free survival (DFS) and overall survival (OS) by Kaplan-Meier analyses and log-rank test. Seven specimens were excluded because of accidental death or lost to follow-up. The DFS results showed the 5-year median survival of $4.1 \mathrm{~B}$ positive patients was 22 months, while the $4.1 \mathrm{~B}$ negative specimens was 15 months. The 5 -year median survival about OS is 51 months in $4.1 \mathrm{~B}$ positive patients, while the 4.1B negative specimens was 33 months. This result showed that 4.1B positive GC patients had better survival time than negative ones (Fig. $1 \mathrm{~b}$ and $\mathrm{c} ; p<0.001$ ).

To further evaluate whether $4.1 \mathrm{~B}$ is an independent factor for GC patient prognosis, we performed the univariate and multivariate COX regression analyses for DFS and OS. The results showed the 4.1B expression, tumor size, lymph metastasis (N0 vs. N1 + N2 + N3) and TNM analyses (I + II vs. III) were the prognostic factor. Further analysis in the multivariate COX regression analyses, 4.1B expression, tumor size and TNM stage were the independent factor for DFS (HR:1.773, CI:1.036-3.035, $P=$ 0.037; HR:1.694, CI:1.023-2.803, $P=0.040$ and HR:1.923, CI:1.161-3.184, $P=0.011)$ and OS (HR:1.691, CI:1.0132.823, $P=0.045$; HR:2.025, CI:1.242-3.302, $P=0.005$ and HR:2.197, CI:1.365-3.534, $P=0.001$ ) (Table 3).

We also investigated $4.1 \mathrm{~B}$ protein expression in two GC cell lines with starkly different rates of proliferation (Fig. 2A). There was a clear detection of a prominent protein band at $130 \mathrm{kDa}$ in the MKN45 cell line. However, no such band was detected in the MGC-803 cell line (Fig. 2A). The mRNA level of 4.1B was also consistent with the protein result by real-time PCR (data not shown). These results suggest that $4.1 \mathrm{~B}$ was inversely associated with the proliferation of GC cell lines.

\subsection{B suppresses $G C$ cell proliferation in vitro}

To further explore the effect of $4.1 \mathrm{~B}$ in GC cell lines, we transiently transfected MGC-803 cells with pEGFP-4.1B to exogenously increase 4.1B expression. Conversely, 4.1B double nickase plasmid was transfected transiently to silence the expression of endogenous 4.1B. Real-time PCR and western blot analysis confirmed successful overexpression at 
Table 2 Correlation of 4.1B expression with clinical parameters in GC patients

\begin{tabular}{|c|c|c|c|c|c|}
\hline \multirow[t]{2}{*}{ Variables } & \multirow{2}{*}{$\begin{array}{l}\text { No. }(n= \\
102)\end{array}$} & \multicolumn{2}{|c|}{ 4.1Bexpression } & \multirow[t]{2}{*}{$x^{2}$} & \multirow{2}{*}{$\begin{array}{l}p \\
\text { value }\end{array}$} \\
\hline & & Negative(46) & Positive(56) & & \\
\hline \multicolumn{6}{|l|}{ Age (years) } \\
\hline$<65$ & 49 & 21 & 28 & \multirow[t]{2}{*}{0.191} & \multirow[t]{2}{*}{0.662} \\
\hline$\geq 65$ & 53 & 25 & 28 & & \\
\hline \multicolumn{6}{|l|}{ Gender } \\
\hline Male & 59 & 27 & 32 & \multirow[t]{2}{*}{0.025} & \multirow[t]{2}{*}{0.847} \\
\hline Female & 43 & 19 & 24 & & \\
\hline \multicolumn{6}{|c|}{ Helicobacter pylori infection } \\
\hline Positive & 56 & 24 & 32 & \multirow[t]{2}{*}{0.252} & \multirow[t]{2}{*}{0.616} \\
\hline Negative & 46 & 22 & 24 & & \\
\hline \multicolumn{6}{|l|}{ Tumor size } \\
\hline$<5 \mathrm{~cm}$ & 56 & 19 & 37 & \multirow[t]{2}{*}{6.257} & \multirow[t]{2}{*}{$0.012^{*}$} \\
\hline$\geq 5 \mathrm{~cm}$ & 46 & 27 & 19 & & \\
\hline \multicolumn{6}{|l|}{ Tumor location } \\
\hline Cardia & 26 & 6 & 20 & \multirow[t]{4}{*}{6.956} & \multirow[t]{4}{*}{0.073} \\
\hline body & 26 & 13 & 13 & & \\
\hline Antrum & 41 & 22 & 19 & & \\
\hline Whole & 9 & 5 & 4 & & \\
\hline \multicolumn{6}{|l|}{ WHO classification } \\
\hline Tubular & 32 & 10 & 22 & \multirow[t]{4}{*}{5.281} & \multirow[t]{4}{*}{0.152} \\
\hline Signet-ring cell & 29 & 14 & 15 & & \\
\hline Mucinous & 37 & 21 & 16 & & \\
\hline Others & 4 & 1 & 3 & & \\
\hline \multicolumn{6}{|c|}{ Pathologic differentiation } \\
\hline G1 & 14 & 4 & 10 & 8.025 & $0.018^{*}$ \\
\hline G2 & 35 & 11 & 24 & & \\
\hline G3 & 53 & 31 & 22 & & \\
\hline Vascular invasion & & & & & \\
\hline Negative & 42 & 15 & 27 & 2.539 & 0.111 \\
\hline Positive & 60 & 31 & 29 & & \\
\hline Neural invasion & & & & & \\
\hline Negative & 43 & 17 & 26 & 0.929 & 0.335 \\
\hline Positive & 59 & 29 & 30 & & \\
\hline Depth of invasion & & & & & \\
\hline $\mathrm{T} 1+\mathrm{T} 2$ & 26 & 8 & 18 & 2.894 & 0.089 \\
\hline $\mathrm{T} 3+\mathrm{T} 4$ & 76 & 38 & 38 & & \\
\hline Lymph metastasis & & & & & \\
\hline No & 26 & 7 & 19 & 4.656 & $0.031^{*}$ \\
\hline $\mathrm{N} 1+\mathrm{N} 2+\mathrm{N} 3$ & 76 & 39 & 37 & & \\
\hline TNM stage & & & & & \\
\hline 1 & 19 & 3 & 16 & 8.589 & $0.014^{*}$ \\
\hline$\|$ & 26 & 12 & 14 & & \\
\hline III & 57 & 31 & 26 & & \\
\hline
\end{tabular}

${ }^{*} p<0.05$ the mRNA and protein level and knockout at protein level (Fig. 2B-a and b; C-a).

Figure $2 \mathrm{~B}-\mathrm{d}$ showed that $4.1 \mathrm{~B}$ overexpression suppressed proliferation of MGC803 in comparison to pEGFP-C3 control at different time points $(p<0.001)$. Conversely, proliferation was promoted in 4.1B-silenced MKN45 cells (Fig. 2C-b; $p<0.001$ ).

Collectively, these results demonstrated that $4.1 \mathrm{~B}$ can suppress GC cell proliferation. These results suggest that $4.1 \mathrm{~B}$ can act as a tumor suppressor gene in GC cells.

\subsection{B suppresses tumor growth in vivo}

To further examine the role of $4.1 \mathrm{~B}$ in tumor progression in vivo, we injected the four cell lines (MGC-803 pEGFP-4.1B $(4.1 \mathrm{~B}+/+)$, pEGFP-C3 control $(4.1 \mathrm{~B}-/-)$ and MKN-45 4.1B KO (4.1B -/-), NIC control (4.1B $+/+)$ ) subcutaneously into the right subaxillary region of nude mice. Tumors were visible after 1 week, and the size of tumors was measured every other day by a Vernier caliper. All the mice were sacrificed when the maximum diameter reached $20 \mathrm{~mm}$. Results showed tumorigenic ability was weakened in 4.1B-overexpressing MGC-803 cells. Tumor volume was smaller than control MGC-803 GFP-only cells (4.1B -/-) (Fig. 3a and b; $p<$ 0.001). Subcutaneous injection of MKN-45 cells with 4.1B gene depletion resulted in larger tumors than the NIC control $(4.1 \mathrm{~B}+/+$ ) (Fig. 3e and f; $p<0.001)$. Tumor weight was consistent with tumor volume. Tumors from 4.1B-deficient cells were heavier than tumors from 4.1Bsufficient cells (Fig. $3 \mathrm{c}$ and g; $p<0.001$ and $p<0.05$ ). The mitotic ability, as shown by Ki-67 staining, was suppressed in 4.1B-sufficient cells (Fig. 3d, h).

\subsection{B suppresses $G C$ cell proliferation by affecting the EGFR/MAPK/ERK1/2 and PI3K/AKT pathways}

Previous studies have focused on the relationship between 4.1B and cell differentiation [17], adhesion [30], motility [31], and apoptosis [32]. There were also some studies on 4.1B and cell proliferation, but these studies were limited to a characterization of cell cycle proteins [33]. We wanted to further explore the mechanisms by which 4.1B affects cell proliferation.

Cell proliferation is commonly regulated by the EGFR/ MAPK and PI3K/AKT pathways. Therefore, we examined changes in these two key signaling pathways by western blot. Figure 4 showed that $4.1 \mathrm{~B}$ deficiency resulted in markedly increased levels of ERK1/2 and AKT phosphorylation. Total ERK1/2 and AKT protein levels remained unchanged. $4.1 \mathrm{~B}$ did not affect $\mathrm{p} 38$ and JNK phosphorylation or their corresponding total protein levels. Interestingly, we observed that $4.1 \mathrm{~B}$ loss resulted in an increase in the protein level of EGFR (Fig. 4). 
Table 3 Univariate and multivariate COX regression analyses 4.1B for DFS or OS in GC patients

\begin{tabular}{|c|c|c|c|c|c|c|}
\hline \multirow[t]{2}{*}{ Variables } & \multicolumn{3}{|l|}{ DFS } & \multicolumn{3}{|l|}{ OS } \\
\hline & $\mathrm{HR}$ & $95 \% \mathrm{Cl}$ & $p$ value & $\mathrm{HR}$ & $95 \% \mathrm{Cl}$ & $p$ value \\
\hline \multicolumn{7}{|l|}{ Univariate analysis } \\
\hline 4.1B expression (Positive vs. Negative) & 2.654 & $1.626-4.332$ & $<0.001^{*}$ & 2.547 & $1.584-4.095$ & $<0.001^{*}$ \\
\hline Age (<65 years vs. $\geq 65$ years) & 1.092 & $0.676-1.766$ & 0.719 & 0.879 & $0.551-1.400$ & 0.586 \\
\hline Gender (male vs. female) & 0.910 & $0.558-1.482$ & 0.704 & 0.953 & $0.593-1.530$ & 0.841 \\
\hline HP infection (Positive vs. Negative) & 1.131 & $0.699-1.832$ & 0.616 & 1.161 & $0.726-1.857$ & 0.533 \\
\hline Tumor size $(<5 \mathrm{~cm}$ vs. $\geq 5 \mathrm{~cm})$ & 1.993 & $1.230-3.230$ & $0.005^{*}$ & 2.260 & $1.403-3.640$ & $0.001^{*}$ \\
\hline Tumor location (Cardia+body vs. Antrum +Whole) & 1.413 & $0.872-2.289$ & 0.160 & 1.374 & $0.861-2.194$ & 0.183 \\
\hline WHO classification (Tubular + Signet-ring cell vs. Mucinous+ Others) & 1.247 & $0.770-2.022$ & 0.369 & 1.128 & $0.705-1.805$ & 0.616 \\
\hline Pathologic differentiation (G1 + G2 vs. G3) & 1.229 & $0.867-1.742$ & 0.247 & 1.066 & $0.771-1.473$ & 0.699 \\
\hline Vascular invasion (Positive vs. Negative) & 1.229 & $0.752-2.010$ & 0.411 & 1.142 & $0.709-1.840$ & 0.584 \\
\hline Neural invasion (Positive vs. Negative) & 1.213 & $0.748-1.968$ & 0.433 & 1.288 & $0.804-2.064$ & 0.293 \\
\hline Depth of invasion (T1 + T2 vs. T3 + T4) & 1.429 & $0.814-2.508$ & 0.214 & 0.938 & $0.563-1.563$ & 0.807 \\
\hline Lymph metastasis (N0 vs. N1 + N2 + N3) & 2.266 & $1.211-4.238$ & $0.010^{*}$ & 1.980 & $1.117-3.512$ & $0.019^{*}$ \\
\hline TNM stage (I + II vs. III) & 2.317 & $1.428-3.760$ & $0.001^{*}$ & 2.578 & $1.657-4.011$ & $<0.001^{*}$ \\
\hline \multicolumn{7}{|l|}{ Multivariate analysis } \\
\hline 4.1B expression (Positive vs. Negative) & 1.773 & $1.036-3.035$ & $0.037^{*}$ & 1.691 & $1.013-2.823$ & $0.045^{*}$ \\
\hline Tumor size $(<5 \mathrm{~cm}$ vs. $\geq 5 \mathrm{~cm})$ & 1.694 & $1.023-2.803$ & $0.040^{*}$ & 2.025 & $1.242-3.302$ & $0.005^{*}$ \\
\hline Lymph metastasis (N0 vs. N1 + N2 + N3) & 1.724 & $0.903-3.289$ & 0.099 & 1.458 & $0.807-2.632$ & 0.211 \\
\hline TNM stage (I + II vs. III) & 1.923 & $1.161-3.184$ & $0.011^{*}$ & 2.197 & $1.365-3.534$ & $0.001^{*}$ \\
\hline
\end{tabular}

Deficiency of 4.1B leads to hyperproliferation of MEF cells due to increased EGFR expression

We then examined the proliferation of immortalized MEFs derived from wild type and 4.1B knockout mice. Figure 5A shows increased proliferation of 4.1B knock-out MEF cells. The increased proliferations were accompanied by the increased phosphorylation of ERK1/2, AKT and EGFR (Fig. 5B). Interestingly, while there were no changes in protein levels of ERK1/2 and AKT, total EGFR protein level was also upregulated in immortalized 4.1B KO MEFs (Fig. 5B). These findings suggest that 4.1B may affect cell proliferation by regulating EGFR. The finding that EGFR

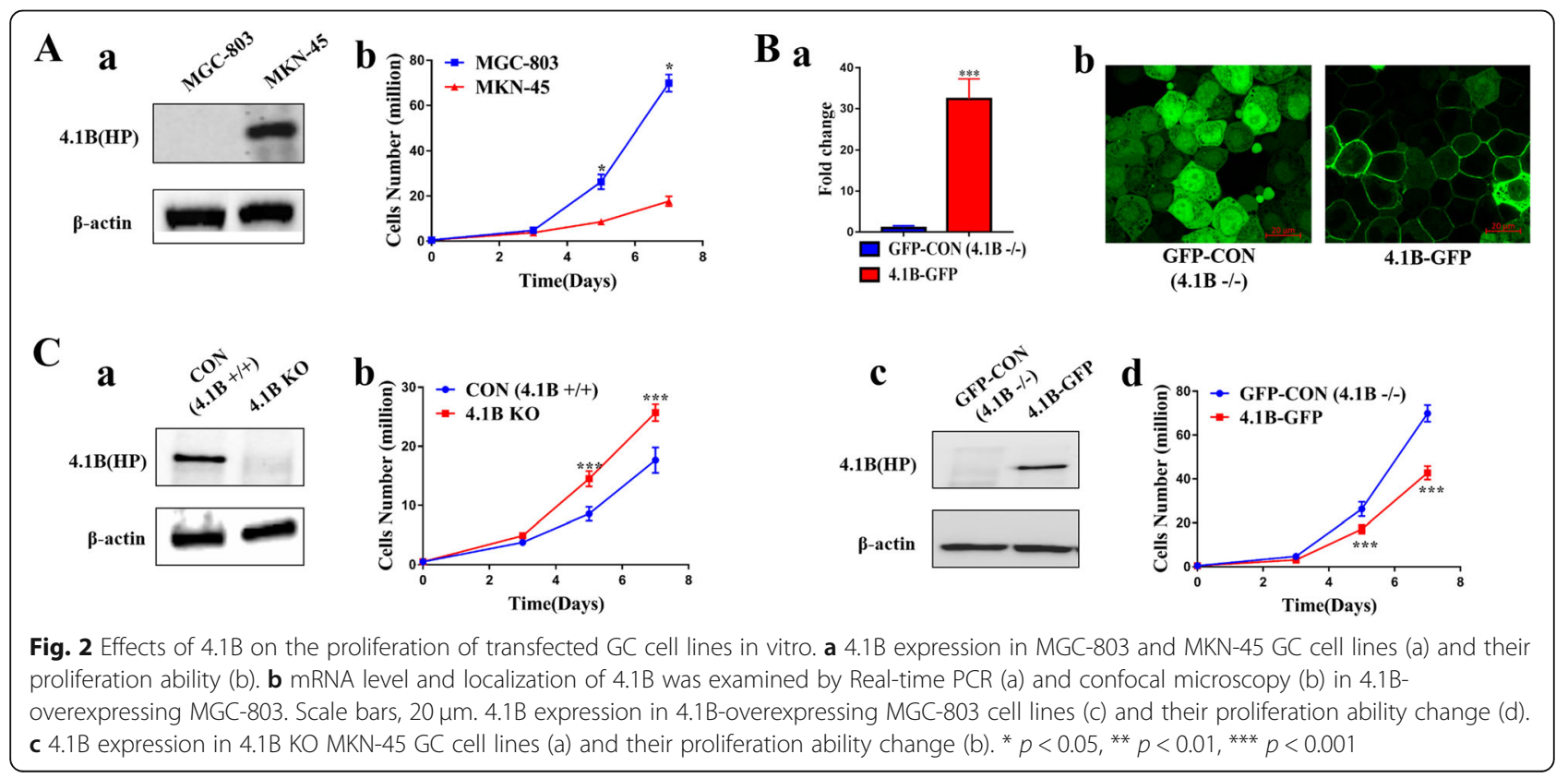




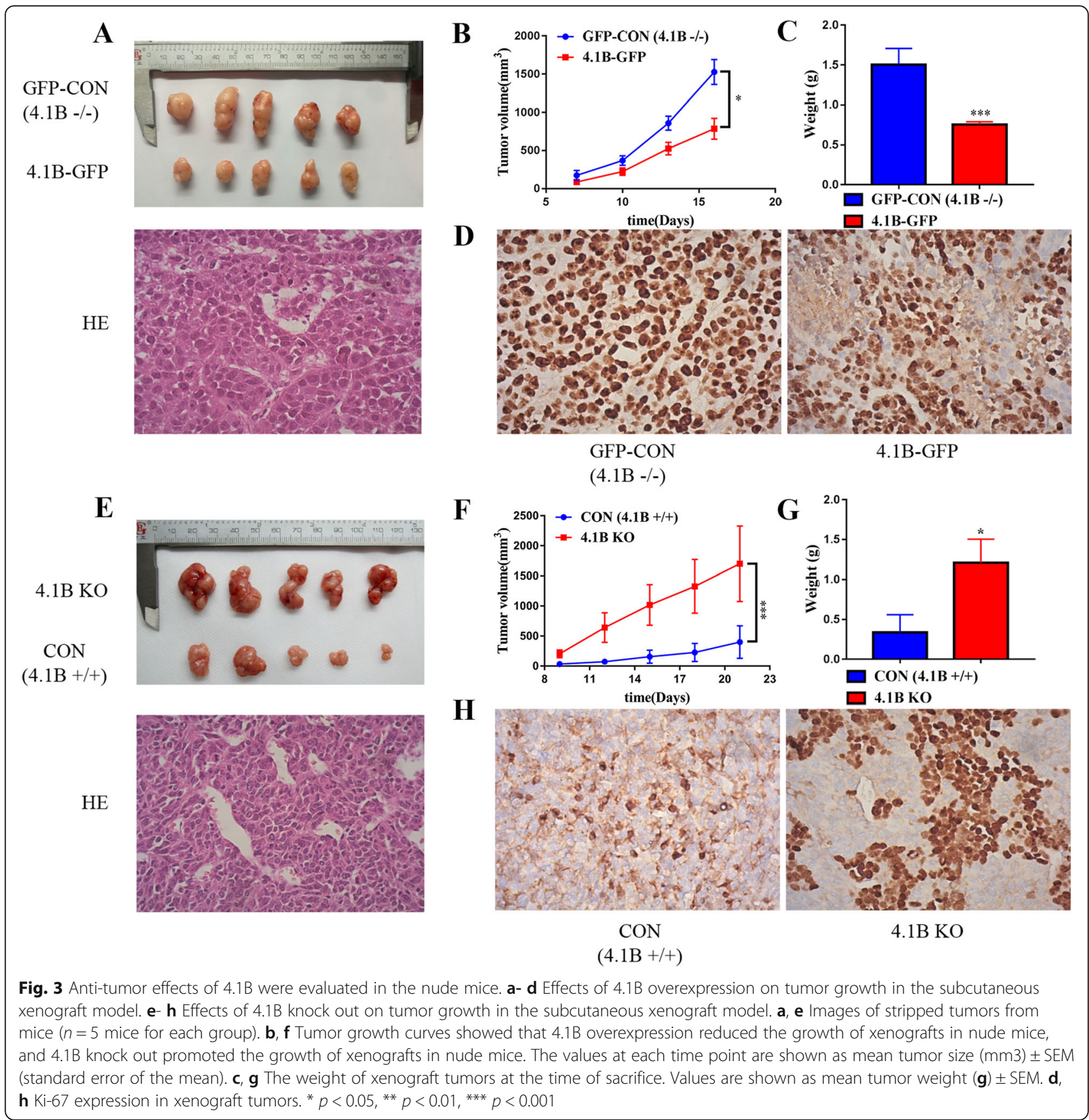

inhibitor erlotinib inhibited the proliferation of 4.1B $\mathrm{KO}$ MEFs (Fig. 5C) supports this hypothesis. To investigate the mechanisms for the increased EGFR protein level, we examined the mRNA levels of EGFR in 4.1B-sufficient and 4.1B-deficient cells by real time PCR. Figure 5D shows negative correlation between 4.1B expression and EGFR mRNA levels in various cell types, demonstrating that deficiency of 4.1B leads to increased EGFR transcription.

To further define mechanisms for the increased mRNA level of EGFR, we examined the expression of Sp1, the transcription factor for EGFR. The data in Fig.
$5 \mathrm{E}$ shown that $4.1 \mathrm{~B}$ deficiency led to increased expression of Sp1. Interestingly, knockdown of Sp1 in 4.1B-deficient cells led to decreased EGFR expression at mRNA and protein level (Fig. 5F).

Given the consistency in the data between MEFs and GC cell lines, we used MEFs as the experimental model in subsequent assays.

\section{Association of 4.1B with EGFR in MEF cells}

We next examined the association of 4.1B with EGFR in MEF cells. Figure 6a shows that while GFP was diffusely 


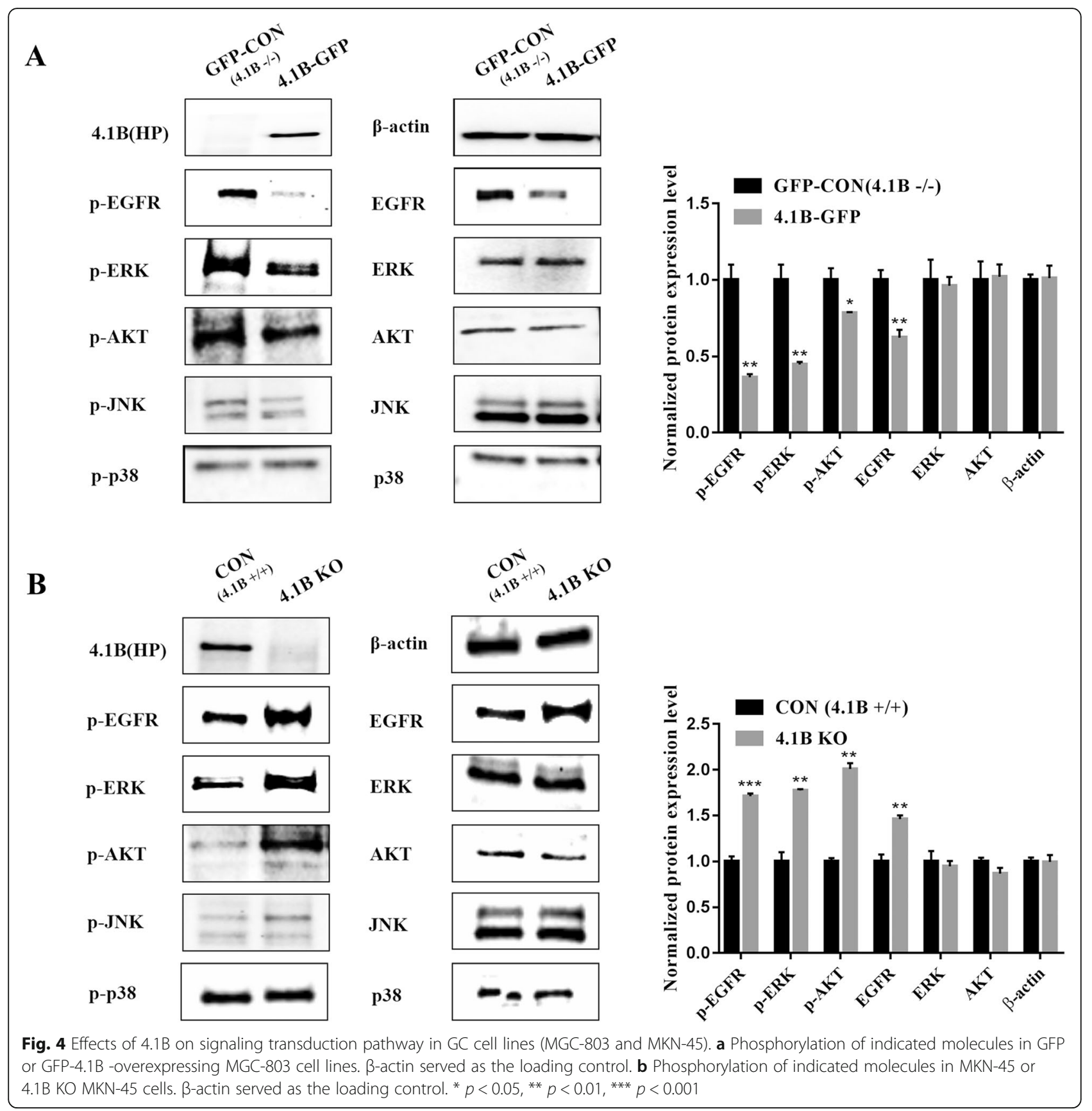

located in the cytosol, GFP-4.1B co-localized with EGFR at the plasma membrane. Moreover, Fig. $6 \mathrm{~b}$ shows that endogenous EGFR was pulled down by an anti-4.1B HP antibody and that endogenous $4.1 \mathrm{~B}$ was pulled down by an anti-EGFR antibody. These findings suggest that 4.1B binds to EGFR.

\subsection{B FERM domain binds to EGFR JM segments}

To further characterize the direct binding between 4.1B and EGFR, we performed a GST pull-down assay using 3 different GST-tagged EGFR intracellular fragments: fragment with JM region (amino acids fragment 644-955 (EGFR1)), fragment without (amino acids fragment 9561186 (EGFR2)) JM region, and fragment with JM fragment with the first 13 amino acids deleted (EGFR1 $\triangle$ aa13) (amino acids fragment 644-955) (Fig. 7a).

We found that 4.1B interacted with EGFR JM fragment with the first 13 key amino acids (Fig. 7b). The P13 sequence of EGFR JM segment is "RRRHIVRKRTLRR" (aa13). We designed three biotin-tagged P13 mutated fragments (AAAHIVRKRTLRR (EGFR P13(RRR-AAA)), RRRHIVAAATLRR (EGFR P13(RKR-AAA), and 
A

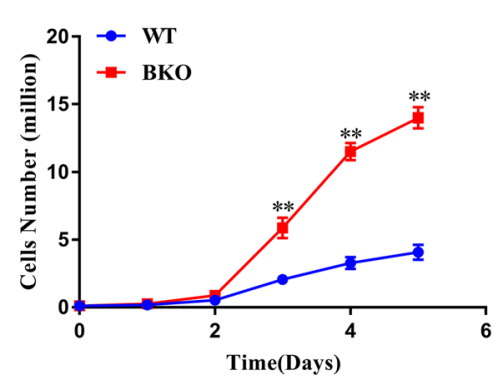

C

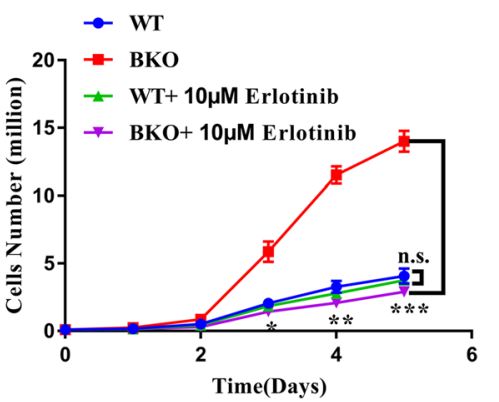

D

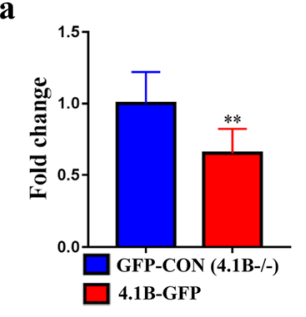

E

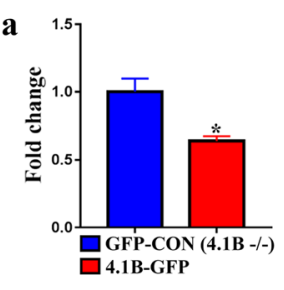

b

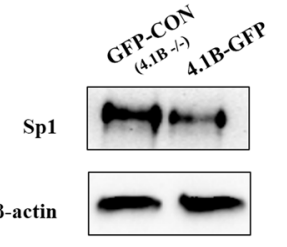

F a

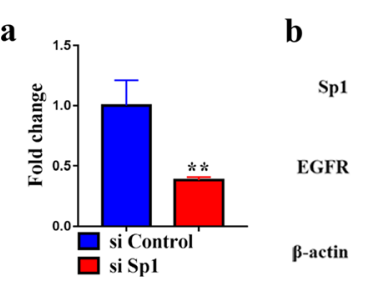

d
B
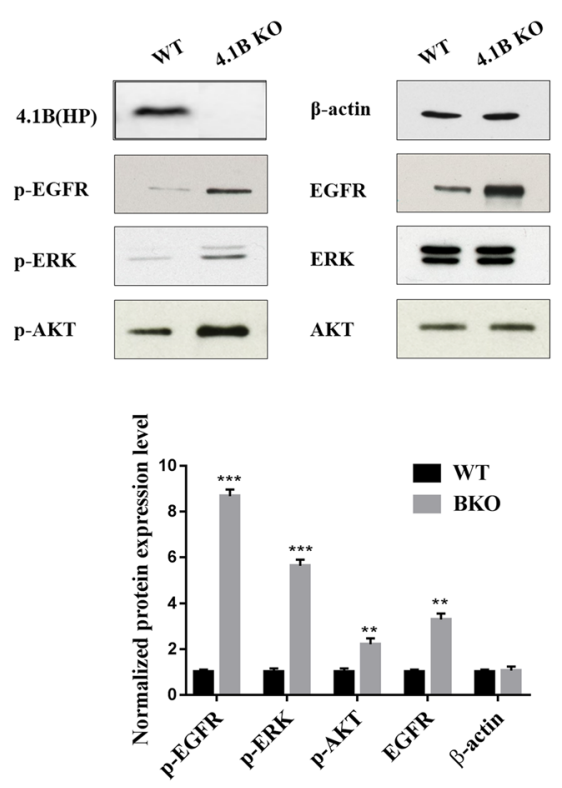

c
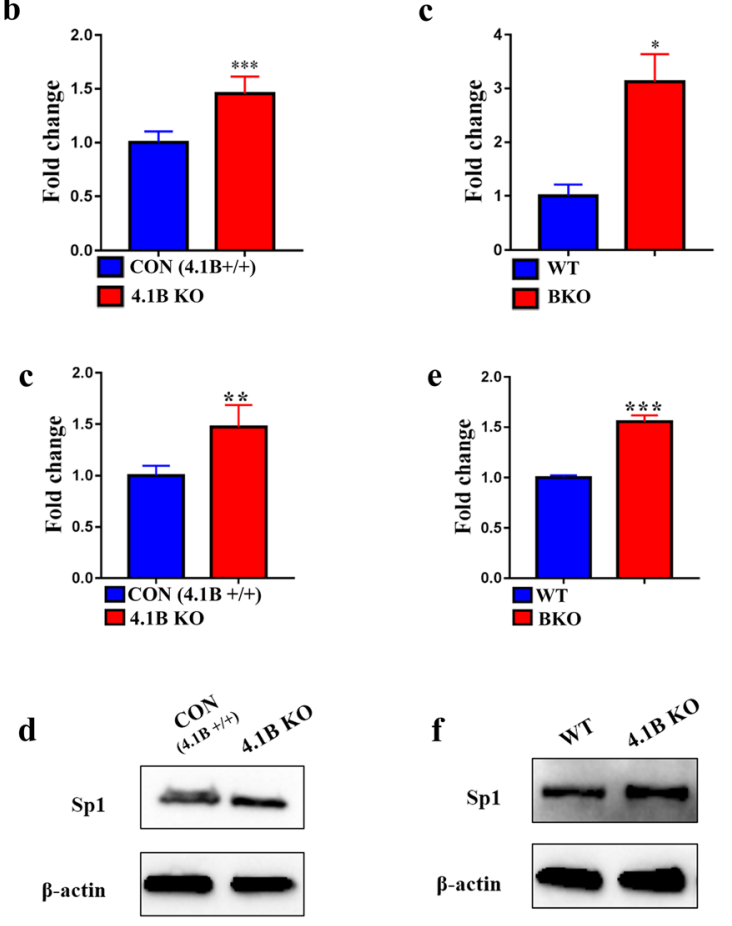

d
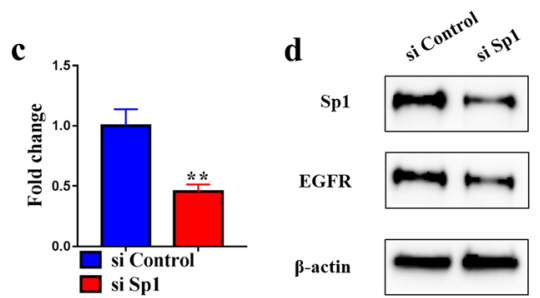

Fig. 5 (See legend on next page.) 
(See figure on previous page.)

Fig. 5 Hyperproliferation and enhanced EGFR-mediated signal transduction of immortalized 4.1B KO MEF cells. a Proliferation of immortalized WT MEF and 4.1B KO MEF. $\mathbf{b}$ Increased phosphorylation of EGFR, ERK and AKT in 4.1B KO MEF cells. $\beta$-actin served as the loading control. $\mathbf{c}$ Effects of erlotinib on cell proliferation. $\mathbf{d}$ Expression of EGFR mRNA levels in various cell types as indicated: GFP or GFP-4.1B -overexpressing MGC-803 cell lines (a); MKN-45 or 4.1B KO MKN-45 cells (b); immortalized WT MEF and 4.1B KO MEF (c). e Decreased expression of Sp1 mRNA and protein levels in 4.1B overexpressing MGC-803 cells (a; b) and increased expression of Sp1 mRNA and protein levels in 4.1B-deficient MKN-45 cells (c; d) and 4.1B KO-MEF cells (e; f). $\mathbf{f}$ Decreased expression of EGFR in Sp1 knockdown cells (4.1B-deficient MKN-45 cells mRNA level (a) and protein level (b)); (4.1B KO-MEF cells mRNA level (c) and protein level (d)). ${ }^{*} p<0.05,{ }^{* *} p<0.01,{ }^{* * *} p<0.001$

RRRHIVRRRTL $A A$ (EGFR P13(RR- $A A)$ ) (Fig. 7a). Binding was eliminated when two or three amino acids were randomly mutated (Fig. 7b). We also performed a GST pull-down assay using GST-tagged 4.1B domains. The FERM domain of 4.1B was found to bind with EGFR intact JM fragment (Fig. 7c). In summary, we have defined the binding sites involved in 4.1B-EGFR interaction. This interaction is schematically represented in Fig. $7 d$.

\section{Discussion}

The results of our study have highlighted a novel function for $4.1 \mathrm{~B}$ as a tumor suppressor, which inhibits proliferation of gastric cancer cells. Additionally, we demonstrate the details of the sites involved in interaction between 4.1B and EGFR. This study is the first to document the mechanism by which $4.1 \mathrm{~B}$ inhibits tumor cell proliferation by binding to the JM segment of EGFR.

Previous studies showed that different cancers express little to no 4.1B [14-17] due to promoter hypermethylation $[14,19,34-36]$. Only a few studies have assessed $4.1 \mathrm{~B}$ in GC $[18,19]$. Our study examined the correlation of $4.1 \mathrm{~B}$ with $\mathrm{GC}$ clinical parameters. The IHC results showed that $4.1 \mathrm{~B}$ was mainly expressed in the cell plasma membrane and was downregulated in GC adenocarcinoma. Our clinical data also demonstrated that 4.1B can affect tumor size, pathologic differentiation, vascular invasion, and TNM stage. The expression of $4.1 \mathrm{~B}$ is also associated with patient overall survival (OS). These results suggest that $4.1 \mathrm{~B}$ may serve as a tumor suppressor in gastric cancer.

Several studies have alluded to the molecular mechanisms underlying the oncogenic effect of 4.1B deficiency. Sakurai-Yageta et al. reported that 4.1B regulated CADM1 to affect epithelial cell adhesion. CADM1 associates with 4.1B/DAL-1 through the 4.1B binding motif, while loss of the CADM1-4.1B/DAL-1 complex may affect cancer cell adhesion and enhance cancer cell invasion and/or metastasis [30]. Other studies have shown that 4.1B/DAL-1 can anchor F-actin to the cell membrane, thereby inhibiting cell motility by supporting orderly arrangement of actin stress fibers. Loss of the 4.1B/DAL-1 complex may promote F-actin reorganization and enhance cell motility, which in turn, may increase tumor migration [15]. Other studies have also reported $4.1 \mathrm{~B}$ regulation of cell mobility through the activity of adhesion molecules [15, 30, 37, 38].

In this study, we focused on the functional role of $4.1 \mathrm{~B}$ in gastric cancer cell proliferation. Although studies have examined the relationship of $4.1 \mathrm{~B}$ and GC $[18,19]$, there have been no reports of the functional effect of $4.1 \mathrm{~B}$ on GC cell proliferation. We investigated the relationship between

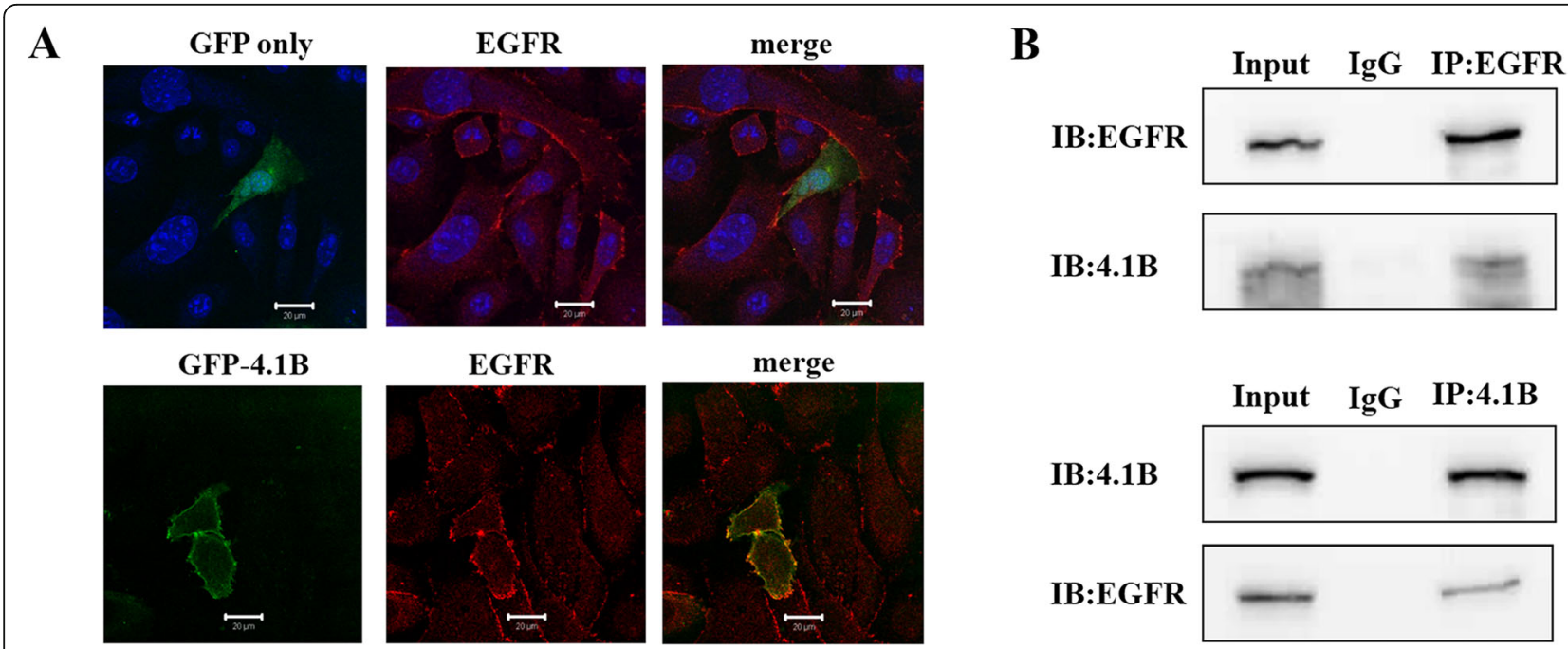

Fig. 6 Interaction of 4.1B with EGFR in immortalized MEF cells. a 4.1B co-localization with EGFR in immortalized WT MEF by IF. Scale bars, 20 Hm. b $4.1 \mathrm{~B}$ binds to EGFR by Co-IP 


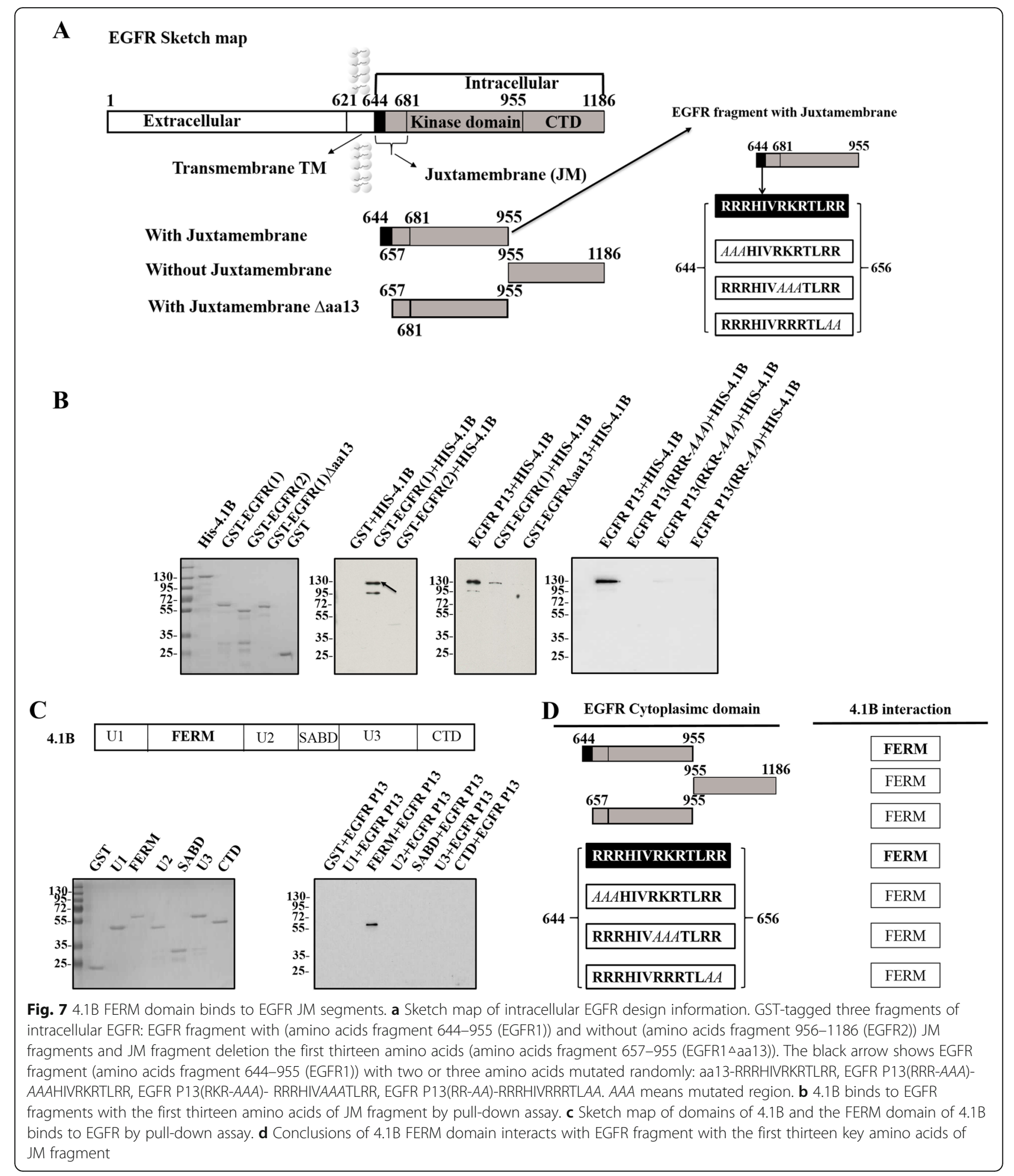

protein 4.1B and proliferation and tumorigenicity using preclinical in vitro and in vivo models of GC. Our results showed that 4.1B can inhibit tumor cell proliferation. Robb et al., Gerber et al., and Kuns et al. have reported that the $\mathrm{U} 2$ domain of $4.1 \mathrm{~B}$ can affect cell proliferation by activating
Src, Rac1, MLK3, and JNK, resulting in reduced expression cyclin $\mathrm{A}$ and decreased retinoblastoma $(\mathrm{Rb})$ protein hyperphosphorylation $[33,39,40]$.

We found that 4.1B blocked GC cell line proliferation through the proto-oncogenic EGFR/MAPK/ERK1/2 and 
PI3K/AKT signaling pathways. Of note, we observed that perturbing 4.1B expression in GC cell lines resulted in a change in the levels of total EGFR. Similar effects on proliferation and EGFR levels were observed in immortalized 4.1B deficiency MEFs.

We used an EGFR inhibitor to address our hypothesis that $4.1 \mathrm{~B}$ can inhibit EGFR-mediated cell proliferation in immortalized 4.1B deficiency MEFs. Our results also showed that 4.1B can suppress EGFR mRNA levels.

Activation of EGFR requires more than just ligand engagement to the extracellular EGFR segment. EGFR dimerization also requires coupling of the transmembrane domain and JM segment [41]. The initial 13 amino acids (P13) within the intracellular JM region (R645-R657) are required for proper dimerization and autophosphorylation of EGFR [42]. 4.1B is localized to the plasma membrane and is distributed along cell-cell junctions [26], as well as cell-basement membrane contacts [33]. Therefore, we hypothesized that $4.1 \mathrm{~B}$ could bind to the P13 region of the EGFR JM segment to block EGFR activation. Our IF staining and co-IP assay demonstrated that $4.1 \mathrm{~B}$ can indeed, directly bind to EGFR. Our pull-down assay clearly showed 4.1B interaction with the P13 region of the EGFR JM fragment. We further demonstrated that the FERM domain of $4.1 \mathrm{~B}$ can bind to the P13 region of the EGFR JM segment.

Our schematic diagram (Fig. 8) explains clearly the mechanism of $4.1 \mathrm{~B}$ blocking cells proliferation by inhibiting the EGFR synthesis. The combination of protein 4.1B with P13 of EGFR JM segments blocks the binding of EGFR monomers intracellular JM segments. This blocking hinders EGFR monomers dimerization and autophosphorylation, and the conformational coupling is stopped. Thus, EGFR activation and autophosphorylation is suppressed in 4.1B-sufficient cancer cells. This can explain why the phosphorylated EGFR was down-regulated in our transfected GC cells and MEF cells with protein $4.1 \mathrm{~B}$ existence. The data showed that phosphorylated ERK1/2 was down-regulated by inhibition of EGFR/Ras/Raf/ERK1/2 pathway.

\section{Conclusion}

Our findings are significant and novel. First, our results clearly showed that 4.1B functions as a tumor suppressor in GC. Our study is also the first report of 4.1B inhibition of GC cell proliferation by binding to EGFR monomers. This is also the first demonstration of the precise domains of $4.1 \mathrm{~B}$ and EGFR that facilitate their interaction. Given the importance of EGFR signaling in cancer cell growth and tumor progression, our study highlights a potential new therapeutic target for gastric cancer. Our data suggest that 4.1B-targeting may be a viable strategy to combat tumor progression in gastric cancer patients.

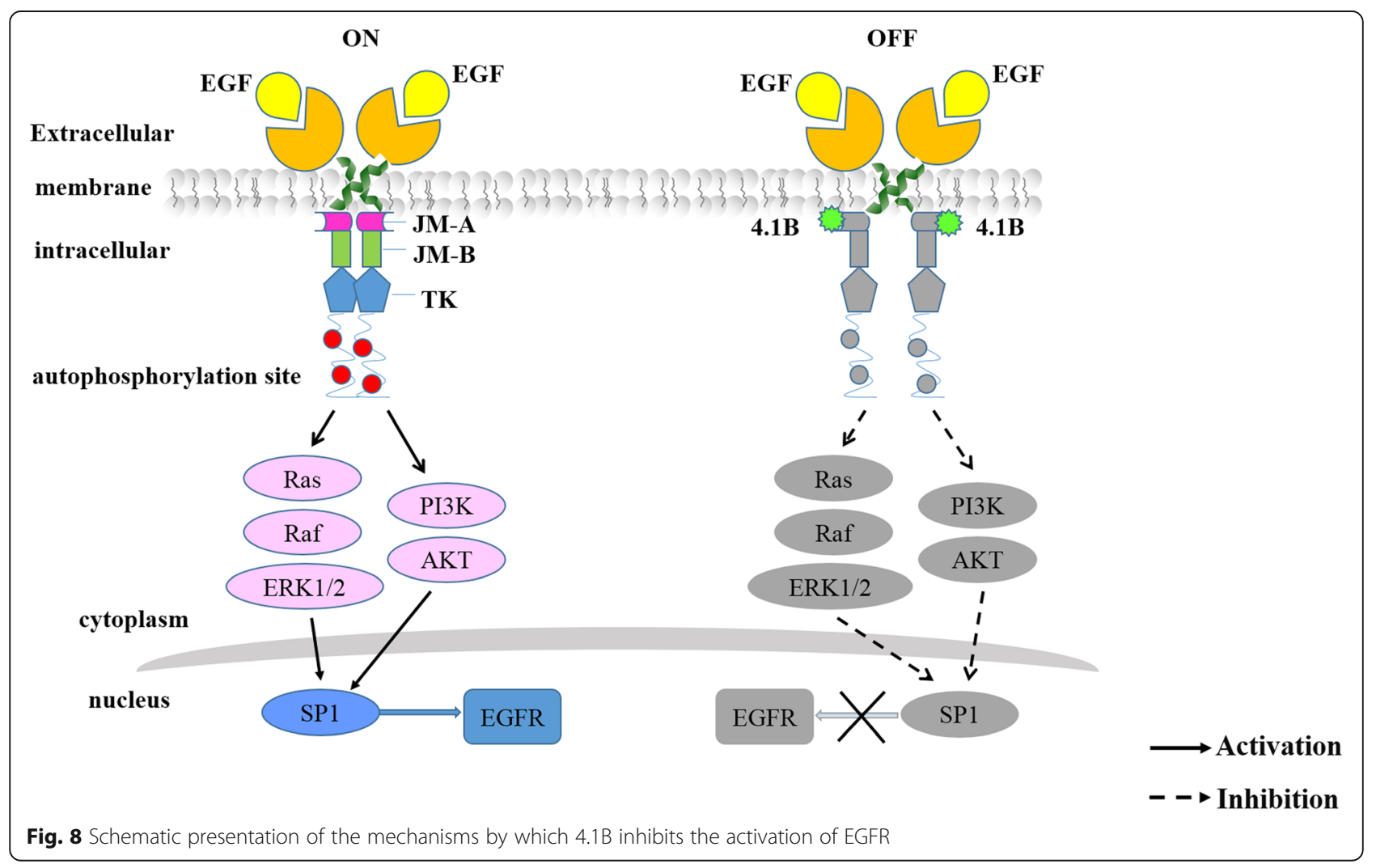




\section{Abbreviations}

AJCC: American Joint Committee on Cancer; BKO: 4.1B knock-out; Co-IP: Coimmunoprecipitation; DFS: Disease-free survival; DMEM: Dulbecco Modified Eagle Medium; EGFR: Epidermal growth factor receptor; FBS: Fetal bovine serum; GC: Gastric cancer; HE: Hematoxylin and eosin; IF: Immunofluorescence; JM: Juxtamembrane; MEF: Mouse embryonic fibroblasts; OS: Overall survival; P13: Initial 13 amino acids; Sp1: Specificity protein 1; SPF: Specific pathogen-free; WT: Wild type

\section{Acknowledgements}

We thank LetPub (www.letpub.com) for its linguistic assistance during the preparation of this manuscript.

\section{Authors' contributions}

The project was conceived by XA and PZ. Experiments were performed by FX and CA. GL and LM provided support for clinical data analysis. FR designed Real-time PCR primers sequence. FX, XA and PZ wrote the manuscript. LC edited the manuscript. XG, HS, XS and JL provided help for pathological tissues study. All authors read and approved the final manuscript.

\section{Funding}

National natural Science Foundation of China (grant number 81370494); International Science and Technology Cooperation Project of Henan Province in China (grant number 182102410018); Excellent Foreign Scientist Studio of Henan Province in China (grant number GZS2018001); Medical service capacity improvement project of Henan Province in China (grant number Yu Wei Medicine [2017] No.66); National Natural Science Foundation of China (grant number 31471330); the Foundation of Henan Science and Technology Department (grant number 172102410014); Henan Provincial Medical Science and Technology Research Joint Co-construction Project (grant number 2018020224); The key scientific research project of the Foundation of Henan Educational Committee (FHEC, \#18A320011), and the major project of the Foundation of Zhengzhou Collaborative Innovation ( $\mathrm{FZCl}$, \#18XTZX12003).

\section{Availability of data and materials}

The datasets used and/or analysed during the current study are available from the corresponding author upon request. All data generated or analysed during this study are included in this published article.

\section{Ethics approval and consent to participate}

The present study was approved by the Research Ethics Committee of Institute of Clinical Medicine, the Fifth Affiliated Hospital of Zhengzhou University. All participants signed informed consent for scientific research.

\section{Consent for publication}

Not applicable.

\section{Competing interests}

The authors declare that they have no competing interests.

\section{Author details}

'Department of Gastroenterology, the Fifth Affiliated Hospital of Zhengzhou University, Zhengzhou 450052, Henan, China. ${ }^{2}$ Key Laboratory of $\mathrm{H}$. pylori and Gastrointestinal Microecology of Henan Province, the Fifth Affiliated Hospital of Zhengzhou University, Zhengzhou 450052, Henan, China. ${ }^{3}$ Department of Hematology, the First Affiliated Hospital of Zhengzhou University, Zhengzhou 450052, Henan, China. ${ }^{4}$ School of Life Sciences, Zhengzhou University, Zhengzhou 450001, Henan, China. ${ }^{5}$ Department of Public Health, Zibo Integrate traditional Chinese \& Western Medicine Hospital, Zibo 255000, Shandong, China. ${ }^{6}$ Red Cell Physiology, New York Blood Center, New York, NY 10065, USA. 7 Department of Pathology, the Fifth Affiliated Hospital of Zhengzhou University, Zhengzhou 450052, Henan, China. ${ }^{8}$ Department of Pediatrics, the Fifth Affiliated Hospital of Zhengzhou University, Zhengzhou 450052, Henan, China. ' ${ }^{2}$ aboratory of Membrane Biology, New York Blood Center, New York, NY 10065, USA.
Received: 6 June 2019 Accepted: 29 August 2019

Published online: 06 September 2019

\section{References}

1. Liao KF, Chiu TL, Huang SY, Hsieh TF, Chang SF, Ruan JW, Chen SP, Pang CY, Chiu SC. Anti-Cancer effects of Radix Angelica Sinensis (Danggui) and NButylidenephthalide on gastric Cancer: implications for REDD1 activation and mTOR inhibition. Cell Physiol Biochem. 2018;48:2231-46.

2. Ferlay J, Soerjomataram I, Dikshit R, Eser S, Mathers C, Rebelo M, Parkin DM, Forman D, Bray F. Cancer incidence and mortality worldwide: sources, methods and major patterns in GLOBOCAN 2012. Int J Cancer. 2015;136:E359-86.

3. Lee JH, Kim JG, Jung HK, Kim JH, Jeong WK, Jeon TJ, Kim JM, Kim Yl, Ryu KW, Kong SH, et al. Clinical practice guidelines for gastric cancer in Korea: an evidence-based approach. J Gastric Cancer. 2014;14:87-104.

4. Van Cutsem E, Sagaert X, Topal B, Haustermans K, Prenen H. Gastric cancer. Lancet. 2016;388:2654-64.

5. Takeuchi K, Kawashima A, Nagafuchi A, Tsukita S. Structural diversity of band 4.1 superfamily members. J Cell Sci. 1994;107(Pt 7):1921-8.

6. Peters LL, Weier HU, Walensky LD, Snyder SH, Parra M, Mohandas N, Conboy JG. Four paralogous protein 4.1 genes map to distinct chromosomes in mouse and human. Genomics. 1998;54:348-50.

7. Chishti AH, Kim AC, Marfatia SM, Lutchman M, Hanspal M, Jindal H, Liu SC, Low PS, Rouleau GA, Mohandas N, et al. The FERM domain: a unique module involved in the linkage of cytoplasmic proteins to the membrane. Trends Biochem Sci. 1998;23:281-2.

8. Han BG, Nunomura W, Takakuwa Y, Mohandas N, Jap BK. Protein 4.1R core domain structure and insights into regulation of cytoskeletal organization. Nat Struct Biol. 2000;7:871-5.

9. Busam RD, Thorsell AG, Flores A, Hammarstrom M, Persson C, Obrink B, Hallberg BM. Structural basis of tumor suppressor in lung cancer 1 (TSLC1) binding to differentially expressed in adenocarcinoma of the lung (DAL-1/4. 1B). J Biol Chem. 2011;286:4511-6.

10. Baines AJ. A FERM-adjacent (FA) region defines a subset of the 4.1 superfamily and is a potential regulator of FERM domain function. BMC Genomics. 2006;7:85.

11. Correas I, Speicher DW, Marchesi VT. Structure of the spectrin-actin binding site of erythrocyte protein 4.1. J Biol Chem. 1986;261:13362-6.

12. Gimm JA, An X, Nunomura W, Mohandas N. Functional characterization of spectrin-actin-binding domains in 4.1 family of proteins. Biochemistry. 2002; 41:7275-82

13. Scott C, Phillips GW, Baines AJ. Properties of the C-terminal domain of 4.1 proteins. Eur J Biochem. 2001;268:3709-17.

14. Yamada D, Kikuchi S, Williams YN, Sakurai-Yageta M, Masuda M, Maruyama T, Tomita K, Gutmann DH, Kakizoe T, Kitamura T, et al. Promoter hypermethylation of the potential tumor suppressor DAL-1/4.1B gene in renal clear cell carcinoma. Int J Cancer. 2006;118:916-23.

15. Dafou D, Grun B, Sinclair J, Lawrenson K, Benjamin EC, Hogdall E, KrugerKjaer S, Christensen L, Sowter HM, Al-Attar A, et al. Microcell-mediated chromosome transfer identifies EPB41L3 as a functional suppressor of epithelial ovarian cancers. Neoplasia. 2010;12:579-89.

16. Chen X, Cheung ST, So S, Fan ST, Barry C, Higgins J, Lai KM, Ji J, Dudoit S, $\mathrm{Ng} \mathrm{IO}$, et al. Gene expression patterns in human liver cancers. Mol Biol Cell. 2002;13:1929-39.

17. Ohno N, Terada N, Murata S, Yamakawa H, Newsham IF, Katoh R, Ohara O, Ohno S. Immunolocalization of protein 4.1B/DAL-1 during neoplastic transformation of mouse and human intestinal epithelium. Histochem Cell Biol. 2004;122:579-86.

18. Li X, Zhang Y, Zhang H, Liu X, Gong T, Li M, Sun L, Ji G, Shi Y, Han Z, et al. miRNA-223 promotes gastric cancer invasion and metastasis by targeting tumor suppressor EPB41L3. Mol Cancer Res. 2011;9:824-33.

19. Wang $H, X u M$, Cui X, Liu Y, Zhang Y, Sui Y, Wang D, Peng L, Wang D, Yu J. Aberrant expression of the candidate tumor suppressor gene DAL-1 due to hypermethylation in gastric cancer. Sci Rep. 2016;6:21755.

20. Ullrich A, Coussens L, Hayflick JS, Dull TJ, Gray A, Tam AW, Lee J, Yarden Y, Libermann TA, Schlessinger J, et al. Human epidermal growth factor receptor CDNA sequence and aberrant expression of the amplified gene in A431 epidermoid carcinoma cells. Nature. 1984;309:418-25.

21. Walton GM, Chen WS, Rosenfeld MG, Gill GN. Analysis of deletions of the carboxyl terminus of the epidermal growth factor receptor reveals selfphosphorylation at tyrosine 992 and enhanced in vivo tyrosine phosphorylation of cell substrates. J Biol Chem. 1990;265:1750-4. 
22. Endres NF, Das R, Smith AW, Arkhipov A, Kovacs E, Huang Y, Pelton JG, Shan Y, Shaw DE, Wemmer DE, et al. Conformational coupling across the plasma membrane in activation of the EGF receptor. Cell. 2013;152:543-56.

23. Hubbard SR, Till JH. Protein tyrosine kinase structure and function. Annu Rev Biochem. 2000;69:373-98.

24. Merlino GT, Xu YH, Richert N, Clark AJ, Ishii S, Banks-Schlegel S, Pastan I. Elevated epidermal growth factor receptor gene copy number and expression in a squamous carcinoma cell line. J Clin Invest. 1985;75:1077-9.

25. Xu YH, Richert N, Ito S, Merlino GT, Pastan I. Characterization of epidermal growth factor receptor gene expression in malignant and normal human cell lines. Proc Natl Acad Sci U S A. 1984;81:7308-12.

26. Wang J, Song J, An C, Dong W, Zhang J, Yin C, Hale J, Baines AJ, Mohandas $\mathrm{N}$, An X. A 130-kDa protein 4.1B regulates cell adhesion, spreading, and migration of mouse embryo fibroblasts by influencing actin cytoskeleton organization. J Biol Chem. 2014:289:5925-37.

27. Yi C, McCarty JH, Troutman SA, Eckman MS, Bronson RT, Kissil JL. Loss of the putative tumor suppressor band 4.1B/Dal1 gene is dispensable for normal development and does not predispose to cancer. Mol Cell Biol. 2005;25:10052-9.

28. Xu J. Preparation, culture, and immortalization of mouse embryonic fibroblasts. Curr Protoc Mol Biol. 2005;28(28):21.

29. Kang Q, Wang T, Zhang H, Mohandas N, An X. A Golgi-associated protein 4. $1 \mathrm{~B}$ variant is required for assimilation of proteins in the membrane. J Cell Sci. 2009;122:1091-9.

30. Sakurai-Yageta M, Masuda M, Tsuboi Y, Ito A, Murakami Y. Tumor suppressor CADM1 is involved in epithelial cell structure. Biochem Biophys Res Commun. 2009:390:977-82

31. Arjonen A, Kaukonen R, Ivaska J. Filopodia and adhesion in cancer cell motility. Cell Adhes Migr. 2011;5:421-30

32. Jiang W, Newsham IF. The tumor suppressor DAL-1/4.1B and protein methylation cooperate in inducing apoptosis in MCF-7 breast cancer cells. Mol Cancer. 2006;5:4

33. Kuns R, Kissil JL, Newsham IF, Jacks T, Gutmann DH, Sherman LS. Protein 4. $1 \mathrm{~B}$ expression is induced in mammary epithelial cells during pregnancy and regulates their proliferation. Oncogene. 2005;24:6502-15.

34. Zeng R, Liu Y, Jiang ZJ, Huang JP, Wang Y, Li XF, Xiong WB, Wu XC, Zhang $J R$, Wang QE, Zheng YF. EPB41L3 is a potential tumor suppressor gene and prognostic indicator in esophageal squamous cell carcinoma. Int J Oncol. 2018;52:1443-54.

35. Takahashi Y, Iwai M, Kawai T, Arakawa A, Ito T, Sakurai-Yageta M, Ito A, Goto A, Saito M, Kasumi F, Murakami Y. Aberrant expression of tumor suppressors CADM1 and 4.1B in invasive lesions of primary breast cancer. Breast Cancer. 2012:19:242-52

36. Kikuchi S, Yamada D, Fukami T, Masuda M, Sakurai-Yageta M, Williams YN, Maruyama T, Asamura H, Matsuno Y, Onizuka M, Murakami Y. Promoter methylation of DAL-1/4.1B predicts poor prognosis in non-small cell lung cancer. Clin Cancer Res. 2005:11:2954-61.

37. Jou TS, Stewart DB, Stappert J, Nelson WJ, Marrs JA. Genetic and biochemical dissection of protein linkages in the cadherin-catenin complex. Proc Natl Acad Sci U S A. 1995;92:5067-71.

38. Knudsen KA, Soler AP, Johnson KR, Wheelock MJ. Interaction of alphaactinin with the cadherin/catenin cell-cell adhesion complex via alphacatenin. J Cell Biol. 1995;130:67-77.

39. Robb VA, Gerber MA, Hart-Mahon EK, Gutmann DH. Membrane localization of the $\mathrm{U} 2$ domain of protein $4.1 \mathrm{~B}$ is necessary and sufficient for meningioma growth suppression. Oncogene. 2005;24:1946-57.

40. Gerber MA, Bahr SM, Gutmann DH. Protein 4.1B/differentially expressed in adenocarcinoma of the lung-1 functions as a growth suppressor in meningioma cells by activating Rac1-dependent c-Jun-NH (2)-kinase signaling. Cancer Res. 2006;66:5295-303.

41. Yarden Y, Schlessinger J. Self-phosphorylation of epidermal growth factor receptor: evidence for a model of intermolecular allosteric activation. Biochemistry. 1987;26:1434-42.

42. Aifa S, Aydin J, Nordvall G, Lundstrom I, Svensson SP, Hermanson O. A basic peptide within the juxtamembrane region is required for EGF receptor dimerization. Exp Cell Res. 2005;302:108-14.

\section{Publisher's Note}

Springer Nature remains neutral with regard to jurisdictional claims in published maps and institutional affiliations.

\section{Ready to submit your research? Choose BMC and benefit from:}

- fast, convenient online submission

- thorough peer review by experienced researchers in your field

- rapid publication on acceptance

- support for research data, including large and complex data types

- gold Open Access which fosters wider collaboration and increased citations

- maximum visibility for your research: over $100 \mathrm{M}$ website views per year

At BMC, research is always in progress.

Learn more biomedcentral.com/submissions 